УДК 782.9:792.027.4:791.221.1]:069 (477)

DOI: 10.37026/2520-6427-2021-107-3-141-145
Антон КАРМАЗІН,

кандидат мистеитвознавства, член Національної спілки композиторів України, науковий співробітник Музею театрального, музичного та кіномистецтвва України,

м. Киӥв, Украӥна

ORCID: 0000000288600355

e-mail: karmazinanton82@ukr.net

\title{
МАРКО КРОПИВНИЦЬКИЙ ТА УКРАЇНСЬКА МУЗИЧНА КУЛЬТУРА (за матеріалами Музею театрального, музичного та кіномистецтва України)
}

\begin{abstract}
Анотація. У статті окреслено музичну сторону діяльності письменника, драматурга, театрального режисера та актора Марка Лукича Кропивницького, щчо певною мірою знаходиться в тіні його літературних $i$ театральних здобутків, однак є не менш иікавою та насиченою, про щуо свідчать експонати Музею театрального, музичного та кіномистецтва Украӥни. Драматурга представлено не лише як непересічного музиканта та співака, в репертуарі якого було чимало українських народних пісень, оперних арій, романсів, а й чития та диригента хору. Марка Кропивницького схарактеризовано як особистість із багатими музичними та вокальними
\end{abstract}

даними, яскравим акторським талантом, які під час перегляду театральних постановок викликали справжне захоплення в глядачів. Оригінальні авторські композиції та український фольклорний матеріал складали основу музичного рішення вистав трупи Кропивницького, які він здійснював самостійно як режсисер та композитор. Представлено артефакти Музею театрального, музичного та кіномистецтва Украӥни, зокрема унікальні матеріали, афіші, рукописи, щзо свідчать про активну діяльність Кропивницького як музиканта.

Ключові слова: Марко Кропивницький, музичне мистецтво, вокал, опера, артефакти.

Anton KARMAZIN,

Candidate in Art History,

Member of the National Union of Composers of Ukraine, Researcher at the Museum of Theater,

Music and Cinema of Ukraine,

Kyiv, Ukraine

ORCID: 0000000288600355

e-mail: karmazinanton82@ukr.net

\section{MARKO KROPYVNYTSKYI AND UKRAINIAN MUSICAL CULTURE (According to the materials of the Museum of theater, music and cinema of Ukraine)}

\begin{abstract}
The article examines the musical side of activity of the writer and actor Marko Kropyvnytskyi. It is to some extent in the shadow of his literary and theatrical achievements, but is no less profound and rich. Some of its features were revealed using the exhibits of the Museum of Theater, Music and Cinematography of Ukraine. His role as an outstanding musician was emphasized, because the repertoire of Kropyvnytskyi - singer included Ukrainian folk songs, opera arias, romances, he began to sing in the church choir.

The functions of the artist in concert activity as a reader, singer and choir conductor are determined. The rich musical and vocal data of a composer with a bright acting talent, which caused real delight of the audience when watching theatrical performances, are analyzed.
\end{abstract}

The original author's compositions and Ukrainian folklore material formed the basis of the musical decision of the performances of the Kropyvnytskyi troupe, which he himself carried out as a director and composer. The role of the Bobrinets amateur circle in the formation of the artist as an actor and an extraordinary theater artist of Ukraine is outlined. In the archives of Mykola Sadovsky, Maria Zankovetska, Mark Kropyvnytsky, there are a lot of handwritten and printed scores for performances, vocal and instrumental works that were performed by actors in Kropyvnytskyi productions. Artifacts of the Museum of Theater, Music and Cinema of Ukraine, which has in the exposition unique materials telling about Kropyvnytskyi-musician (posters, manuscripts), are presented. 
Memories of contemporaries testify to the rich musical and vocal data of the artist, which together with the bright acting talent caused a real delight of the audience. The artist has successfully performed in opera productions, in particular embodied on stage the role of the Cossack Karas in "Zaporozhets beyond the Danube» by S. GulakArtemovsky and the Unknown in "Askold's grave» by O. Verstovsky.

Key words: Marko Kropyvnytskyi, music, vocals, opera, artifacts.

Постановка проблеми. Марко Лукич Кропивницький - яскрава особистість в історії вітчизняної культури, «наділена унікальною різнобічною обдарованістю: класик драматургії, геніальний актор, режисер-реформатор, засновник театру світової слави, талановитий організатор і керівник театру, чудовий педагог, який відшукував у народі таланти і копіткою працею виховував із них майстрів професійної сцени» (Кропивницький I., 2008). Це про нього геніальний Іван Франко сказав: «Твори М. Кропивницького запевняють йому в історії українського театру не тільки ім'я одного з його батьків, але також в історії нашого письменства ім'я визначного драматичного автора».

Проте доля обдарувала Марка Кропивницького не тільки акторським талантом, вона сповна вділила йому й інших щедрот: він був відомим поетом, композитором, диригентом, співаком, а ще - непересічним музикантом (Театральна енциклопедія,1964, с. 63). Саме про Кропивницького як музиканта хочемо розповісти у нашій розвідці, адже музична сторона діяльності видатного митця перебуває дещо «в тіні» порівняно $з$ діяльністю театральною, а отже, потребує додаткової уваги.

Аналіз наукових досліджень і публікацій. Життя та творчість М. Кропивницького грунтовно представлено в роботах А. Новикова, М. Смоленчука, В. Яроша, В. Тобілевича, В. Босько, В. Шурапова, М. Галицького, О. Бабенка, П. Перепелиці та інших дослідників.

Особливої ваги сьогодні набувають також мемуари, листи та документи, представлені Володимиром Кропивницьким - сином прославленого митця, які по-особливому демонструють для сучасників картину його життя і творчої діяльності (насамперед першого десятиліття XX ст.). У зв'язку з цим варто виокремити видання «Із сімейної хроніки Марка Кропивницького (спогади про батька)» (1968).

Мета статті - окреслити роль Марка Кропивницького в українській музичній культурі, використовуючи атрибути та артефакти, представлені в експозиції Музею театрального, музичного та кіномистецтва України.

Виклад основного матеріалу дослідження. Корифей українського театру, видатний режисер, постановник, актор, художник-декоратор Марко Кропивницький (див. рис. 1) славився неабияким талантом музиканта: писав музику, грав на фортепіано, скрипці, віолончелі, гітарі, народних інструментах (бандурі, басолі, сопілці), мав гарний баритон, співав у церковному хорі (Кропивницький В., 1960, с. 160). У репертуарі Кропивницького-співака були українські народні пісні, оперні арії, романси.
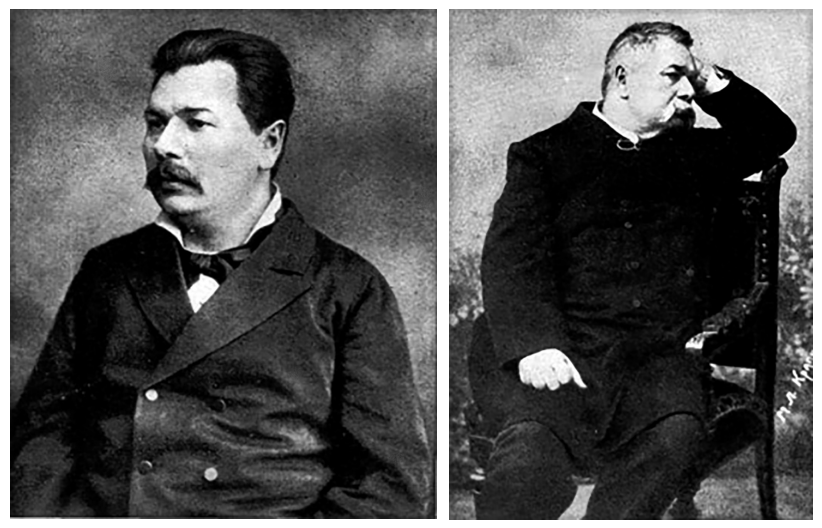

Рис. 1. Портрети М. Кропивницьького, представлені в Музеї музичного, театрального та кіномистеитва Украӥни

Марко Лукич був палким збирачем та видавцем мистецьких творів. Так, постановка Кропивницьким Шевченкового «Назара Стодолі», безумовно, сприяла посиленню суспільної уваги до цього шедевра, на сюжет якого писали музику П. Ніщинський (музика до спектаклю вперше була виконана саме в театральному гуртку Кропивницького), а згодом К. Данькевич (опера) та М. Вериківський (музика до кінофільму). У ході роботи над «Назаром Стодолею», однією із найпопулярніших українських п’єс, завжди поряд із драматургом був режисерський примірник (див. рис. 2), 3 яким він працював.

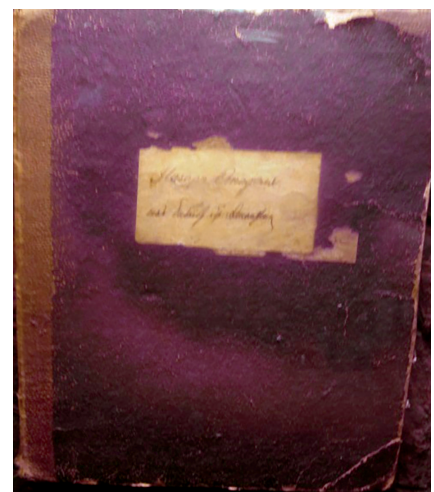

Рис. 2. Режисерський примірник п'єси Т. Шевченка «Назар Стодоля»

Славився Кропивницький і своїм композиторським талантом: «сам оформлював спектаклі своєї трупи та писав до них музику» (Театральна енциклопедія, 1960, с. 28). Відомі, зокрема, його комічна опера «Вій», оперета-дивертисмент «Пісні в лицях, або Зальоти соцького Мусія», дитячі опери «Івасик-Телесик» (1907) та «По щучому велінню» (1907), романси, вокальні дуети, хори.

Син Марка Лукича, Володимир, згадував: «Майже в усіх батькових сценічних творах незмінно панує музична стихія. Пісні героїчні, історичні, ліричні й комічні змінюють одна одну. Сольні номери змінюються хоровими і ансамблями. Мелодії тут частково народні, а більшість створені в народному дусі самим 
Марком Лукичем. Особисте й народне злилися воєдино $<\ldots>$ Сольний спів, дуети, тріо, великі хорові полотна органічно вливаються в драматургічну концепцію вистави» (Кропивницький В., 1960, с. 162).

Оригінальні авторські композиції, переплетені 3 українським фольклором, складали основу музичного рішення вистав трупи Кропивницького, до створення яких він як режисер та композитор підходив надзвичайно ретельно.

Першою вчителькою музики Марка Кропивницького була його мати - Капітоліна Іванівна, яка не тільки мала гарний голос, а й добре грала на роялі та інших інструментах, розучувала з сином вокальні партії. А от творча діяльність драматурга розпочалася у містечку Бобринець. Саме на сцені Бобринецького аматорського гуртка відбулося його формування як актора (Театральна енциклопедія, 1964, с. 280).

Про перші кроки свого становлення як музиканта митець згадував із властивим йому гумором, пам'ятаючи дещо курйозний випадок: «Якось знаменитий диригент Іполит Альтані почув у моєму виконанні партію Мельника в опері Даргомижського «Русалка» та запитав, яку консерваторію я закінчував. Я не

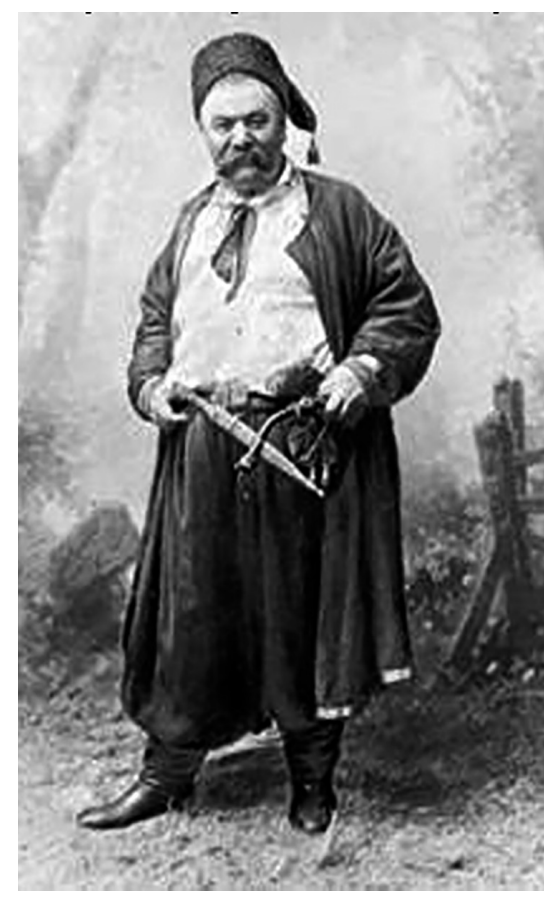

розгубився і відповів - Бобринецьку» (Кропивницький В., 1960, с. 162).

За спогадами сучасників, Кропивницький цілком міг би досягти значних успіхів у кар'єрі оперного та концертуючого співака. Його прекрасні музичні та вокальні дані у поєднанні з яскравим акторським талантом викликали справжнє захоплення в глядачів. Письменник Степан Петров (відомий під псевдонімом Скиталець) порівнював обдарування Кропивницького 3 талантом Федора Шаляпіна: «У Кропивницького, як і в Шаляпіна, було все: сценічний талант (починаючи від трагічних ролей та закінчуючи висококомічними), неймовірна музикальність, сценічна зовнішність і багатий голос $<\ldots>$ У співочих ролях у нього поєднувалися першокласний артистичний талант із чудовими голосовими засобами й іншими даними його щедро обдарованої натури» (Скиталець, 1990, с. 126).

Марко Кропивницький брав участь в оперних постановках, утілюючи на сцені різноманітні образи, найбільш колоритними серед яких були козак Карась із «Запорожця за Дунаєм» С. Гулака-Артемовського (див. рис. 3) та Невідомий із «Аскольдової могили» О. Верстовського (див. рис. 4).

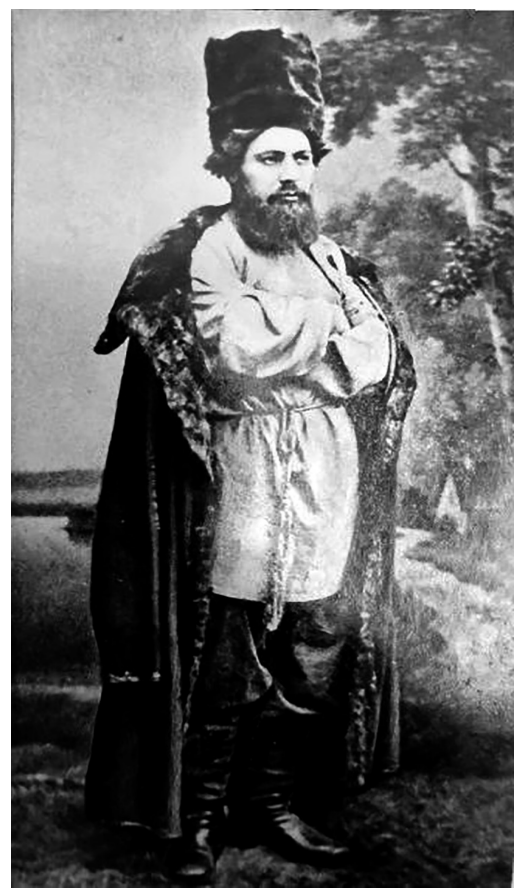

Рис. 3, 4. М. Кропивницький в оперних постановках

Фотографії Кропивницького, на яких він постає у втілених сценічних образах, можна побачити в експозиції Музею театрального, музичного та кіномистецтва України. До речі, постановка «Аскольдової могили» й спів Кропивницького у ролі Невідомого справили надзвичайне враження на антрепренера київської опери Й. Сєтова, який після цього запропонував Марку Лукичу роботу в столичному оперному театрі, однак Кропивницький відмовився від цієї вигідної пропозиції, залишившись у власній трупі.

У путівнику Музею театрального, музичного та кіномистецтва України (2018) зазначається: «Природа українського театру - музично-драматична: в архівах Миколи Садовського, Марії Заньковецької, Марка Кропивницького було чимало рукописних та друкованих нот - це переважно музика, що супроводжувала вистави, вокально-інструментальні твори, які виконували актори...».

В експозиції музею містяться унікальні матеріали, що розповідають про Кропивницького-музиканта. Так, тут можна побачити афішу до вистави «Невольник» (див. рис. 5) за однойменною п’єсою Т. Шевченка, на якій зображено Кропивницького з бандурою у виконанні головної ролі, а також нотний фрагмент із музикою, написаною митцем до цієї постановки (див. рис. 6). У 

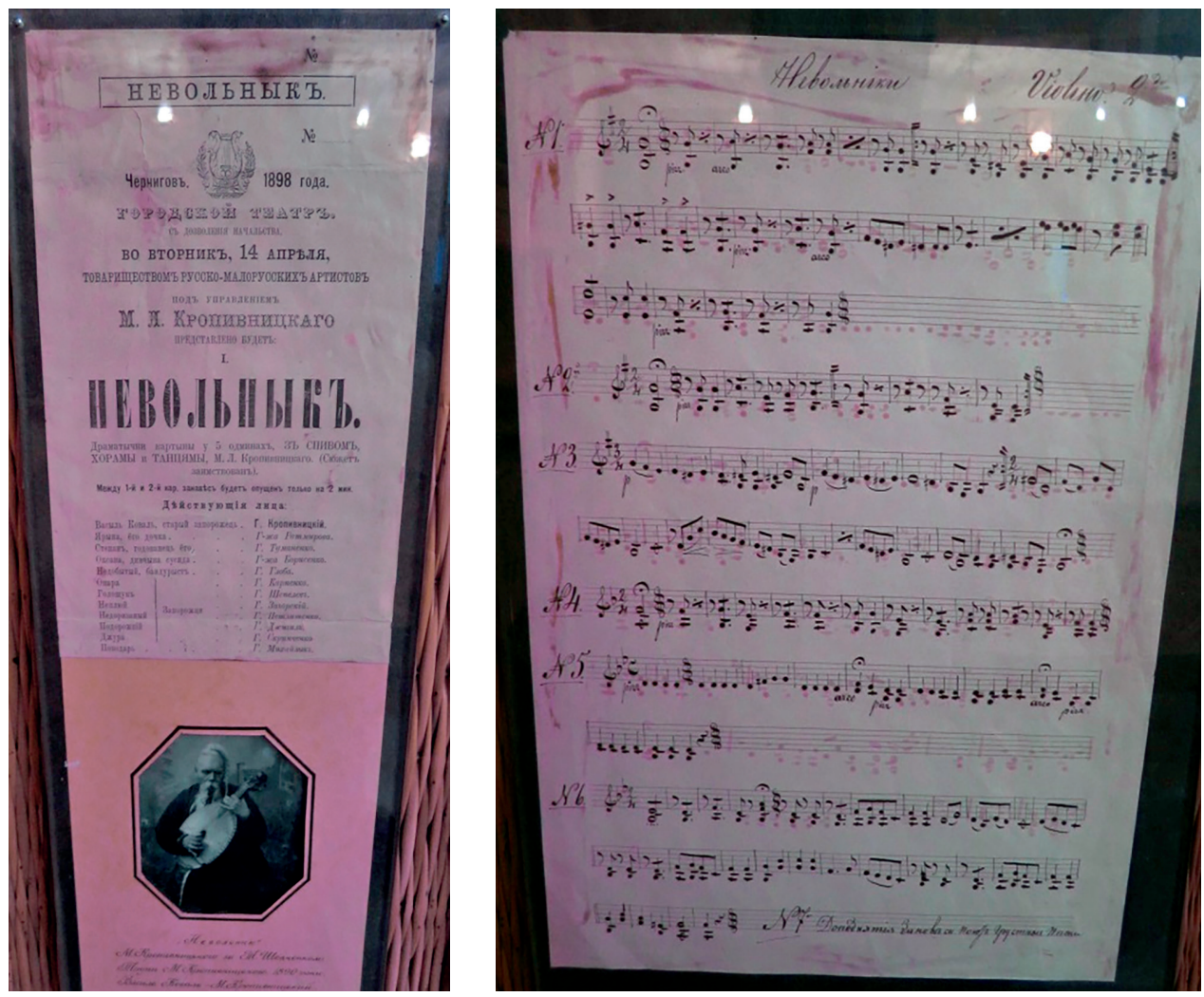

Рис. 5, 6. Афіма постановки п'єси Т. Шевченка «Невольник» та нотний фрагмент із музикою, написаною М. Кропивницьким до иієєї п'єси

цьому спектаклі мелодії народних пісень поєднуються 3 оригінальною авторською музикою.

Митець самостійно підібрав музичний супровід і до власної вистави «По ревізії», увівши в дію для характеристики образу Риндички народну пісню «Ой хто п’є, тому наливайте». Ця п’єса у постановці трупи Кропивницького користувалася величезною популярністю.

Славився Кропивницький і як автор та виконавець пісень на слова Т. Шевченка, зокрема написав музику на вірш поета «За сонцем хмаронька пливе». Він також сам створював слова і музику до пісень, які сьогодні вважаються народними, наприклад, «Соловейко» (див. рис. 7), «Чи я собі не вродливий».

Останні 20 років свого життя Марко Кропивницький мешкав на хуторі із надзвичайно поетичною назвою - Затишок (нині - Шевченківського району Харківської області). Саме тут митець організовує вистави за участю місцевих дітлахів, для яких створює дитячі опери «Івасик-Телесик» та «По щучому велінню». Стосовно першої з них син драматурга Володимир згадує: «Постановка «Івасика» була здійснена у нас на хуторі і в найближчому селі Щенячому (в земській школі). Виконавцями були головним чином селянські діти <..> 3 яким терпінням, любов'ю і творчим запалом працював Марко Лукич зі своєю «дитячою» трупою» (Кропивницький В., 1960, с. 163). Рукописи згаданих вище опер можна побачити в експозиції Музею театрального, музичного та кіномистецтва України.

Сам Марко Кропивницький із цього приводу за-

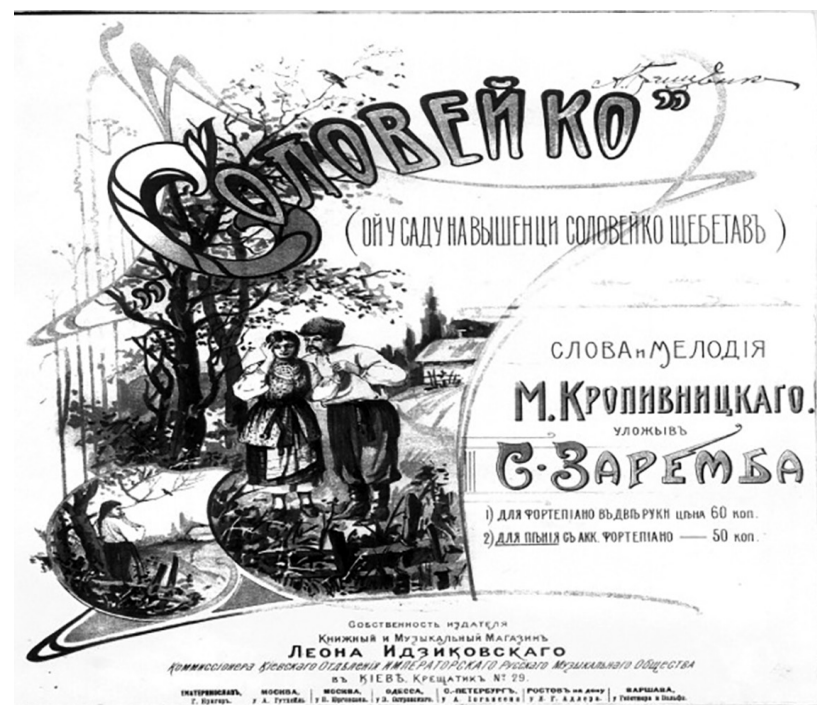

Рис. 7. Раритетне прижиттєве видання «Соловейка»

уважував: «Я собі зібрав трупу з крестьянських дітей і виставляю по селах: «Козу-дерезу», «Івасика-Телесика» і «По щучому велінню» (останні обидві мої)» (Кропивницький, 1960).

Справжньою гордістю Музею театрального, музичного та кіномистецтва України є імпровізований кабінет М. Кропивницького, облаштований за спогадами його сина Володимира (див. рис. 8). 


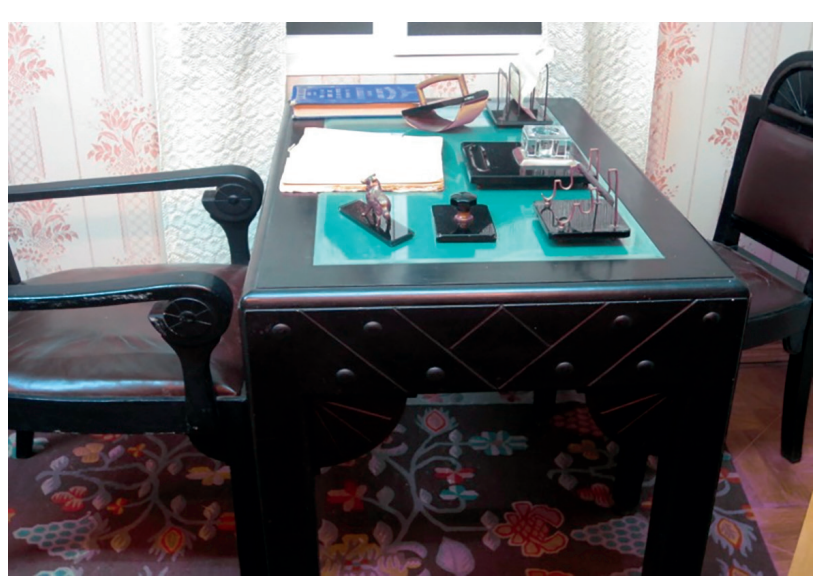

Рис. 8. Робочий стіл М. Кропивницьького

Серед експонатів, наявних в кабінеті, є й ті, що розповідають про Кропивницького-музиканта: патефон для прослуховування платівок та фісгармонія (див. рис. 9), на якій Марко Лукич вечорами виконував прелюдії та хорали Й. Баха.

Але дійсно унікальним раритетом, представленим у музеї, є улюблена скрипка драматурга (див. рис. 10)його незмінна супутниця в усіх подорожах.

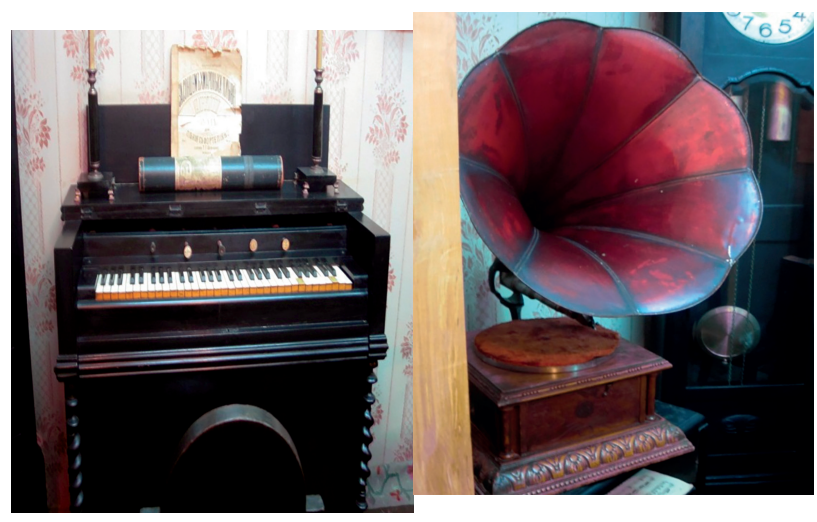

Рис. 9. Патефон та фісгармонія М. Кропивницького

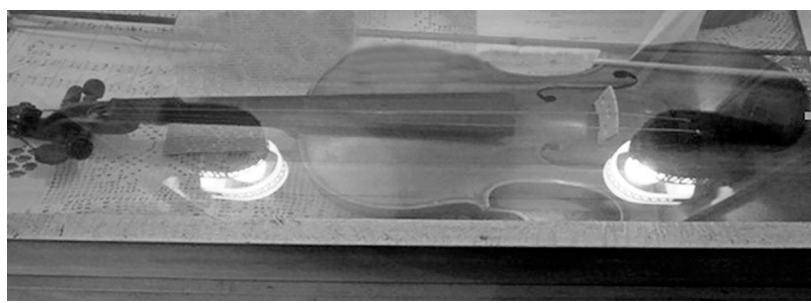

Рис. 10. Скрипка М. Кропивницького

Нині багато що з життя Марка Кропивницького невідоме, а щось позабуте. Але маємо надію, що представлені у статті матеріали допоможуть по-новому поглянути на неординарну особистість видатного митця.

Висновки. Марко Кропивницький увійшов в історію української культури не лише як письменник, драматург, театральний режисер та актор, а й відомий поет, композитор, диригент, співак та обдарований музикант. Як свідчення цьому - представлені нами експонати Музею театрального, музичного та кіномистецтва України, що дозволяють глибоко проникнути у світ мистецтва видатного драматурга шанувальникам його творчості, мистецтвознавцям, науковцям-дослідникам, відкриваючи незвідані сторінки його життя та творчості під час екскурсійних виставок.

Перспективи подальших досліджень. Наші подальші пошуки в означеному напрямі плануємо присвятити вивченню історії української музичної культури, змісту та наповненню нових екскурсійних програм.

\section{СПИСОК ВИКОРИСТАНОЇ ЛІТЕРАТУРИ}

Кропивницький, I. (2008). Батько українського театру. День. № 88. URL: https://day.kyiv.ua/uk/article/kultura/ batko-ukrayinskogo-teatru (дата звернення: 10.05.2021).

Театральная энциклопедия. (1964) / гл. ред. П. А. Марков. Москва: Советская энциклопедия. Т. 3. C. 87.

Кропивницький, В. (1968). Із сімейної хроніки Марка Кропивницького (спогади про батька) / вступ. слово В. Сахновського-Панкєєва; приміт. П. Перепелиці. Київ: Мистецтво. 214 с.

Кропивницький, В. М. (1990). М. Л. Кропивницький як композитор. Спогади про Марка Кропивницького: збірник. Київ: Мистецтво. С. 161-164.

Скиталець. (1990). Про співаків. Спогади про Марка Кропивницького: збірник. Київ: Мистецтво. С. 126-127.

Музей театрального, музичного та кіномистецтва України: путівник (2018) / за ред. І. Дробот. Київ. 50 с.

Кропивницький, М. (1960). Твори: в 6 т. Київ: Держлітвидав УРСР. Т. 6. 672 с.

\section{REFERENCES}

Kropyvnytskyi, I. (2008). Batko ukrainskoho teatru [The father of Ukrainian theater]. Den. № 88. URL: https:// day.kyiv.ua/uk/article/kultura/batko-ukrayinskogo-teatru (data zvernennia: 10.05.2021). [in Ukrainian].

Teatralnaya entsiklopediya [Theatrical encyclopedia] (1964) / gl. red. P. A. Markov. Moskva: Sovetskaya entsiklopediya. T. 3. S. 87. [in Russian].

Kropyvnytskyi, V. (1968). Iz simeinoi khroniky Marka Kropyvnytskoho (spohady pro batka) [From the family chronicle of Mark Kropyvnytsky (memories of his father)] / vstup. slovo V. Sakhnovskoho-Pankieieva; prymit. P. Perepelytsi. Kyiv: Mystetstvo. 214 s. [in Ukrainian].

Kropyvnytskyi, V. M. (1990). M. L. Kropyvnytskyi yak kompozytor [Kropyvnytskyi as a composer]. Spohady pro Marka Kropyvnytskoho: zbirnyk. Kyiv: Mystetstvo. S. 161-164. [in Ukrainian].

Skytalets. (1990). Pro spivakiv[About singers]. Spohady pro Marka Kropyvnytskoho: zbirnyk. Kyiv: Mystetstvo. S. 126-127. [in Ukrainian].

Muzei teatralnoho, muzychnoho ta kinomystetstva Ukrainy [Museum of Theater, Music and Cinematography of Ukraine]: putivnyk (2018) / za red. I. Drobot. Kyiv. 50 s. [in Ukrainian].

Kropyvnytskyi, M. (1960). Tvory: v 6 t. [Works: in 6 vol.]. Kyiv: Derzhlitvydav URSR. T. 6. 672 s. [in Ukrainian].

Дата надходження до редакиії: 06.07.2021 p. 